\title{
Shake-up plans for National Academy of Sciences
}

\section{Washington}

This week, the US National Academy of Sciences (NAS) holds its annual meeting in Washington. Probably more than 300 distinguished scientists will gather. They will not transact much business of substance, but there will be much chat about the Academy's reorganization and the new vision of things of its President, Frank Press, a geophysicist who was President Jimmy Carter's Science Adviser.

The NAS is old by American standards (it was founded by President Abraham Lincoln in 1863) and has been accused of being old-fashioned, especially when it tries to give the government the definitive word on such controversial topics as marijunana use or ozone or acid rain. Clearly the academy's science panels have had difficulty giving advice when the assigned topics have been of emotional national concern. "Most of what the academy has done in the past has been extremely good and very important," says Press. "But if we do fifty reports well and one report badly, often the one report gets all the attention.'

Press wants to retain NAS's reputation for fairness, impartiality and as the country's most authoritative source of science advice. He wants to continue the special relationship the NAS has long held as the government's science advisory group. But he wants reports to come out faster, review procedures to be simpler, and the NAS to exercise leadership in what topics are studied by having independent sources of income to fund self-initiated studies.

These views have already had their effect. Several key studies were initiated, either with Press's advice before or after his taking office, which are half or less fully supported by the government. Among them are:

- University research and national security headed by Dale R. Corsen, former president of Cornell University. It is due to report in a year;

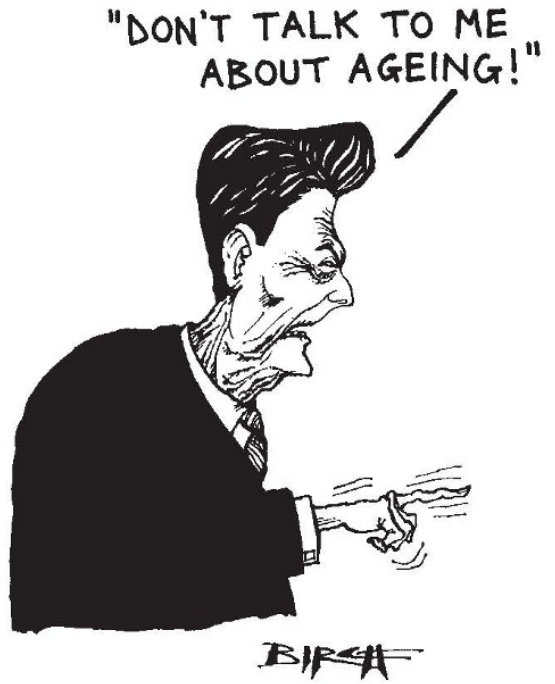

- Government relations with research universities, led by Burke Marshall, professor of law at Yale University. It will study indirect costs, Circular A-21, federal regulation of the laboratory, and will report this summer;

- Relations between the industrial democracies in an era of high technology competition, led by Howard Johnson, Chairman of the corporation, MIT. It is due to report by the end of 1982;

- Arms control and international security, led by Marvin Goldberger, President of California Institute of Technology;

- Ageing. This study is just getting under way. "The government wasn't interested in supporting this" says Press.

Press has started to raise money for NASA's endowment, most of which was raised by former president Frederick Seitz and which now stands at about $\$ 30$ million. Three foundations have given $\$ 3$ million so far and a fourth, the Alfred P Sloan Foundation, has agreed instead to help fund the government-research universitystudy. Meanwhile, NAS's sister organization, the National Academy of Engineering and the Institute of Medicine (IOM), are starting fund-raising drives of their own.

Press is also planning to seek funds from industry through a corporate affiliate programme. "People will say how can you separate donations from control of the work" Press said, anticipating criticism of this move. "We plan to have companies put their membership fees in a blind pool, which we could then draw on without corporate advice to fund our work." In return, member corporations would be invited to special symposia and get all academy reports.

Press, conscious of criticism that academy reports come out slowly and that review procedures are cumbersome, intends to have a special management procedure for the 20 or 30 reports that are nationally significant, thus ensuring that they are "timely" and "dependable".

The studies could be revised faster - " "a review should not take more than 2 or 3 months" says Press. Usually, the board overseeing a study does one review of it; then it goes through an separate review procedure run by the National Research Council, NAS's research arm. Press is experimenting with having both reviews go on at once or having the board waive its review if it has a say in the review run by NRC. Another way to speed up reports is not to insist on consensus, but to let dissenters express their views separately. "I've encouraged that", Press says.

To "simplify"' NAS procedures, Press is abolishing all the assemblies set up by Handler ten years ago, and two of the future commissions. An ad hoc panel under James Ebert, president of the Carnegie Insitution of Washington, looked at the academy structure and recommended changes, most of which have been implemented by NRC in the past month or so (see Nature 1 April p.385).

Under the "streamlined" NAS organisation the old established offices such as the Transportation Research Board and the Office of International Affairs will become their own bosses again, their parent commissions abolished or merged with other things. Agriculture is given new priority, and will probably become its own research board. More attention will be paid to primary and secondary level technical education by the Commission on Behavioural and Social Sciences and Education. What will happen to the

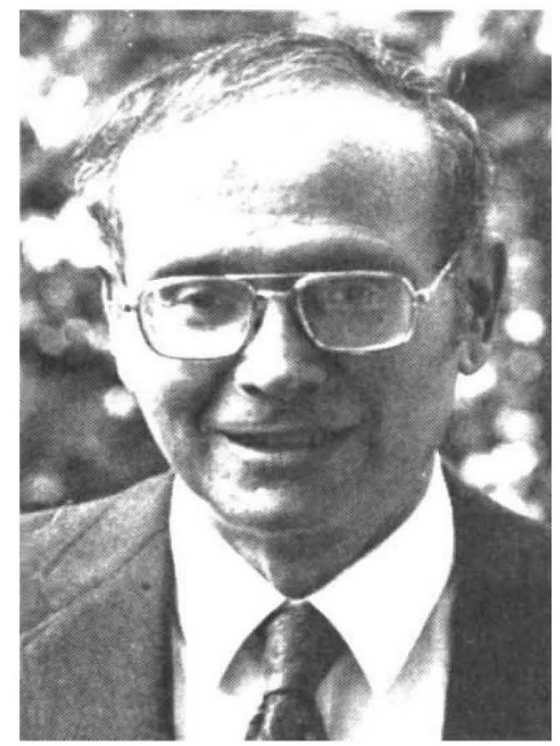

Frank Press - businesslike approach

Institute of Medicine and the Assembly of Life Sciences is uncertain, although there will probably be a new life sciences commission, excluding agriculture. Oceans activities will be consolidated from four boards into two.

Press can implement these changes without a vote of the membership and indeed has already done so. One reason he is seeking non-government money, he says, is to stabilize the staff situation; he plans to hold more regional meetings of members. While most members have accepted the changes, and probably welcome the additional outside funds, Press's businesslike approach to the academy has aroused some murmurs - especially from people in commissions being abolished.

Deborah Shapley

\section{Correction}

Professor E.A. Barnard, not Professor B. Hartley, is head of the biochemistry department at Imperial College, London (Nature, 1 April page 382). Nature apologises to both professors. 